\title{
Tonic and Phasic Nitric Oxide Signals in Hippocampal Long-Term Potentiation
}

\author{
Rachel A. Hopper and John Garthwaite \\ Wolfson Institute for Biomedical Research, University College London, London WC1E 6BT, United Kingdom
}

\begin{abstract}
Nitric oxide (NO) participates in long-term potentiation (LTP) and other forms of synaptic plasticity in many different brain areas but where it comes from and how it acts remain controversial. Using rat and mouse hippocampal slices, we tested the hypothesis that tonic and phasic NO signals are needed and that they derive from different NO synthase isoforms. NMDA increased NO production in a manner that was potently inhibited by three different neuronal NO synthase (nNOS) inhibitors. Tonic NO could be monitored after sensitizing guanylyl cyclase-coupled NO receptors, allowing the very low ambient NO concentrations to be detected by cGMP measurement. The levels were unaffected by inhibition of NMDA receptors, nNOS, or the inducible NO synthase (iNOS). iNOS was also undetectable in protein or activity assays. Tonic NO was susceptible to agents inhibiting endothelial NO synthase (eNOS) and was missing in eNOS knock-out mice. The eNOS knock-outs exhibited a deficiency in LTP resembling that seen in wild-types treated with a NO synthase inhibitor. LTP in the knock-outs could be fully restored by supplying a low level of NO exogenously. Inhibition of nNOS also caused a major loss of LTP, particularly of late-LTP. Again, exogenous NO could compensate, but higher concentrations were needed compared with those restoring LTP in the eNOS knock-outs. It is concluded that tonic and phasic NO signals are both required for hippocampal LTP and the two are generated, respectively, by eNOS and nNOS, the former in blood vessels and the latter in neurons.
\end{abstract}

Key words: nitric oxide synthase; cGMP; guanylyl cyclase; endothelial cell; synaptic plasticity; retrograde messenger

\section{Introduction}

Nitric oxide (NO) contributes widely to synaptic plasticity in the CNS (Garthwaite and Boulton, 1995; Prast and Philippu, 2001). According with the presumed significance of this phenomenon, $\mathrm{NO}$ also participates in several types of learning behavior, a role that spans the evolutionary tree from insects and mollusks up to mammals (Susswein et al., 2004).

NO release in the brain is typically linked to activation of NMDA receptors (Garthwaite and Boulton, 1995), to which the $\mathrm{Ca}^{2+} /$ calmodulin-dependent neuronal NO synthase isoform (nNOS) is tethered (Brenman and Bredt, 1997) and which trigger long-term potentiation (LTP) and other types of synaptic plasticity (Bliss and Collingridge, 1993). On applying LTP-inducing stimuli, NMDA receptor activation elicits a brief burst of NO (Chetkovich et al., 1993; Monfort et al., 2002). In this scenario, NO from nNOS is a good candidate for a retrograde messenger, diffusing rapidly to the presynaptic terminal and effecting changes in the neurotransmitter release machinery (Arancio et al., 1996; Micheva et al., 2003). Postsynaptic effects of NO have also been found (Ko and Kelly, 1999; Lu et al., 1999). NO signal transduction generally occurs through binding to guanylyl cyclase (GC)-coupled NO receptors resulting in the formation of

\footnotetext{
Received May 27, 2006; revised Sept. 25, 2006; accepted Sept. 25, 2006.

This work was supported by The Wellcome Trust and a Biotechnology and Biological Sciences Research Council Cooperative Awards in Science and Engineering Studentship (R.A.H.) partnered by Merck, Sharpe, and Dohme (Harlow, UK). We are grateful to Adrian Hobbs for providing the eNOS knock-out mice, to Barrie Lancaster for help with the electrophysiology, and to Catherine Hall for assistance with statistics.

Correspondence should be addressed to John Garthwaite at the above address. E-mail: john.garthwaite@ud.ac.uk. D0I:10.1523/JNEUROSCI.2259-06.2006

Copyright $\odot 2006$ Society for Neuroscience $\quad$ 0270-6474/06/2611513-09\$15.00/0
}

cGMP, with cGMP-dependent protein kinase being one of the downstream mechanisms leading to changes in synaptic strength (Feil et al., 2005).

Despite the attractiveness of nNOS-derived NO as a messenger associated with NMDA receptor activation and LTP, the main evidence in its favor comes from a pharmacological investigation (Doyle et al., 1996), but the selectivity of the agent used, 7-nitroindazole, is questionable (Alderton et al., 2001). On the contrary, NO-dependent LTP was found to be preserved in nNOS-deficient mice (O'Dell et al., 1994) but lost when the endothelial isoform (eNOS) was knocked out (Wilson et al., 1999; see also Kantor et al., 1996), although a previous study found that a combined deficit in eNOS and nNOS was required to eliminate NO-dependent LTP (Son et al., 1996). Thus, where and how the active NO is formed remains unresolved, and this constitutes an important obstacle in understanding how the pathway functions.

Administration of exogenous NO paired with a weak tetanic stimulation of afferent fibers generates an NMDA receptorindependent LTP (Zhuo et al., 1993; Malen and Chapman, 1997; Bon and Garthwaite, 2003), a result that fulfils a key prediction of the retrograde messenger hypothesis. Surprisingly, however, for exogenous NO to potentiate synaptic transmission in this way, a source of endogenous $\mathrm{NO}$ was needed, both before and after the pairing protocol (Bon and Garthwaite, 2003). Studies on LTP itself also emphasized the importance of tonic NO in that block of NO synthesis shortly ( $5 \mathrm{~min}$ ) after tetanizing the afferent pathway inhibited LTP whereas doing so later (15 min post-tetanus) was ineffective (Bon and Garthwaite, 2003). Collectively, these results imply that tonic and phasic NO signals may both be involved. Here, we have attempted to identify the source of tonic NO and 
determine whether the dual role of NO in LTP might reflect the operation of different NO synthases.

\section{Materials and Methods}

Special chemicals. 1,1-Diethyl-2-hydroxy-2-nitroso-hydrazine sodium (DEA/NO), 5-cyclopropyl-2-\{1-(2-fluorobenzyl)-1 H-pyrazolo[3,4-b] pyridin-3-yl\}pyrimidin-4-ylamine (BAY 41-2272), N-[(3-aminomethyl) benzyl]acetamidine (1400W), vinyl-L-N-5-(1-imino-3-butenyl)-L-ornithine (L-VNIO), $N$-propyl-L-arginine (NPA) and L- $N$-(1-iminoethyl)ornithine (L-NIO) were from Alexis (Nottingham, UK); erythro-9-(2hydroxy-3-nonyl)adenine (EHNA), 3-isobutyl-1-methylxanthine (IBMX), NMDA, wortmannin, and 2-(4-morpholinyl)-8-phenyl-1(4H)-benzopyran-4-one (LY294002) were from Sigma-Aldrich (Poole, Dorset, UK); $1 \mathrm{H}$-[1,2,4] oxadiazolo[4,3-a] quinoxalin-1-one (ODQ), D-(-)-2-amino-5phosphonopentanoic acid (D-AP5), and L-nitroarginine (L-NNA) were from Tocris Cookson, (Avonmouth, UK).

Animals. Rats were 6 to 8 -week-old Sprague-Dawleys from Charles River (Margate, UK). Homozygous eNOS knock-out mice (Huang et al., 1995) were crossed with wild-type 129SV/C57BL/6 mice (Charles River) to generate heterozygotes. Heterozygotes from different litters were mated and their offspring genotyped. Homozygous eNOS knock-outs and their wild-type littermates (both male, $8-12$ weeks old) were used in the experiments. In all studies, the experimenter was blinded to the origin of the mouse tissue until after the results had been analyzed.

Hippocampal slice and aortic ring preparation and maintenance. The animals were killed by a United Kingdom Home Office Schedule 1 method (stunning and decapitation) and their brains dissected out and placed in ice-cold artificial CSF (ACSF) containing the following (in $\mathrm{mm}): 124 \mathrm{NaCl}, 3 \mathrm{KCl}, 1.25 \mathrm{NaH}_{2} \mathrm{PO}_{4}, 1 \mathrm{MgSO}_{4}, 26 \mathrm{NaHCO}_{3}, 2 \mathrm{CaCl}_{2}$, and 10 D-glucose equilibrated with $95 \% \mathrm{O}_{2}, 5 \% \mathrm{CO}_{2}$. Transverse slices ( $0.4 \mathrm{~mm}$ thick) were cut from the central portion of the hippocampus using a Vibratome Series 100 Sectioning system (Technical Products International, St Louis, MO). For electrophysiology, the slices were transferred to an interface holding chamber containing ACSF at room temperature $\left(22-24^{\circ} \mathrm{C}\right)$ for at least $1 \mathrm{~h}$ before use. A slice was then placed in a submerged recording chamber at $30^{\circ} \mathrm{C}$. For cGMP measurement, the slices were allowed to recover in ACSF maintained in a shaking water bath for $1-2 \mathrm{~h}$ at $30^{\circ} \mathrm{C}$. They were then randomized and transferred to fresh solutions. For comparison between hippocampal slices and aortae, stretches of thoracic aorta was taken from the same animals used to supply the hippocampi. After gentle cleaning to remove adhering connective tissue and blood, each aorta was sliced using a razor blade into rings $\sim 3 \mathrm{~mm}$ wide. Usually $6-8$ rings were obtained from each animal. The rings were incubated and randomized in the same way as the hippocampal slices.

Electrophysiology. The methods were as described previously (Bon and Garthwaite, 2003). Briefly, extracellular recordings of field EPSPs (fEPSPs) were made from the stratum radiatum of the CA1 area after electrical stimulation of the Schaffer collateral pathway (baseline frequency, $0.033 \mathrm{~Hz}$ ) at $30^{\circ} \mathrm{C}$. The stimulation strength was adjusted to evoke fEPSPs that had $\sim 30 \%$ of the maximum slope. LTP was induced by either one train of $100 \mathrm{~Hz}$ stimulation (1 s duration), or by three trains of $100 \mathrm{~Hz}$ stimulation (0.1 s duration) delivered $20 \mathrm{~s}$ apart, both at the baseline stimulation intensity. Measurements of the fEPSP slopes were made during their initial linear phase $(20-50 \%$ of the peak) and the values normalized to the mean values recorded in the 10-15 min control period preceding any treatment. Data acquisition and analysis was performed using pCLAMP 8 software (Molecular Devices, Foster City, CA) and in each set of experiments, controls and tests were interleaved.

cGMP measurement. The hippocampal slices were incubated with or without the phosphodiesterase-2 inhibitor EHNA $(300 \mu \mathrm{M})$ for $15 \mathrm{~min}$. Aortic rings were incubated for the same interval with or without the general phosphodiesterase inhibitor IBMX ( $1 \mathrm{mM}$ ). All antagonists to be tested were also included during this period except for wortmannin and LY294002, which were added $30 \mathrm{~min}$ and $10 \mathrm{~min}$ beforehand, respectively. Subsequent exposures to BAY 41-2272, NMDA, or acetylcholine were for 5, 2, and $1 \mathrm{~min}$, respectively. At the end of the experiment, tissues were inactivated in boiling buffer for at least $5 \mathrm{~min}$, homogenized by sonication, and the protein and cGMP contents measured (Bon and Garthwaite, 2003).

NO synthase assay. Freshly isolated hippocampi, or hippocampal slices incubated as in the experiments for cGMP determination, were frozen on dry ice, crushed, and suspended in an ice-cold buffer, $\mathrm{pH}$ 7.2, containing 20 mм HEPES, 1 mm EDTA, 320 mm sucrose, a protease inhibitor mixture (code 873 580; Roche Diagnostics, Lewes, UK), and $10 \mathrm{mg} / \mathrm{ml}$ phenylmethylsulphonyl fluoride. The mixture was sonicated and the protein content determined by the bicinchoninic acid method (Pierce Rockford, IL) with bovine serum albumin as standard. NO synthase activity was measured by the conversion of radiolabeled L-arginine into L-citrulline in the presence of $\mathrm{Ca}^{2+}(200 \mu \mathrm{M})$ or EGTA (1 mM) during 20 min incubation at $37^{\circ} \mathrm{C}$, as described previously (Knowles and Salter, 1998).

Western blotting. Freshly isolated hippocampi from wild-type and eNOS knock-out animals were frozen on dry ice, crushed, and suspended in buffer as described in the NO synthase assay. Tissue extracts from the three animals in each group were pooled and the protein content was determined as above. For the NO synthase isoforms, tissue samples or standards (15 $\mu \mathrm{l} ; 10 \mu \mathrm{g}$ protein) were combined with $5 \mu \mathrm{l}$ of fourfold concentrated loading buffer comprising $250 \mathrm{~mm}$ Tris, $8 \%(\mathrm{w} / \mathrm{v})$ SDS, $0.04 \%(\mathrm{w} / \mathrm{v})$ bromophenol blue, $40 \%(\mathrm{v} / \mathrm{v})$ glycerol, and $20 \%(\mathrm{v} / \mathrm{v})$ $\beta$-mercaptoethanol, $\mathrm{pH} 6.8$, and heated to $100^{\circ} \mathrm{C}$ for $5 \mathrm{~min}$. Standards were a rat pituitary lysate for nNOS and an activated RAW 264.7 macrophage cell lysate for iNOS (both from Affinity Research Products, Exeter, UK). Proteins were separated by electrophoresis on a 10\% SDS-PAGE gel, transferred to nitrocellulose membrane (Hybond ECL; Amersham Biosciences, Amersham, UK) and blocked for $2 \mathrm{~h}$ at room temperature in $5 \%(\mathrm{w} / \mathrm{v})$ nonfat milk in a blotting buffer containing $80 \mathrm{mM} \mathrm{Na}_{2} \mathrm{HPO}_{4}, 20$ $\mathrm{mm} \mathrm{NaH} \mathrm{PO}_{4}, 100 \mathrm{~mm} \mathrm{NaCl}$ and $0.1 \%$ (v/v) Tween 20, pH 7.2. Membranes were incubated overnight at $4^{\circ} \mathrm{C}$ with monoclonal antibodies against eNOS, iNOS, and nNOS (BD Biosciences, Oxford, UK; all 1:2000). The membranes were washed three times in blotting buffer and then incubated in anti-mouse horseradish peroxidase-conjugated secondary antibody (DAKO, Ely, UK; 1:4000) for $1 \mathrm{~h}$ at room temperature. After another three washes, protein bands were visualized using an enhanced chemiluminescence kit (ECL Plus; Amersham Biosciences).

Statistics. All data are presented as means \pm SEM. Statistical differences were analyzed by one-way or two-way ANOVA with Tukey's post hoc test. For all LTP data, the final $20 \mathrm{~min}$ period of recording was analyzed; $p$ values of $<0.05$ were regarded as significant.

\section{Results}

\section{Selective inhibition of nNOS in hippocampal slices}

Much effort has gone into the discovery of selective inhibitors of the different NO synthase isoforms, from which a number of compounds selective for nNOS have now become available (Erdal et al., 2005). An alternative approach of using of nNOSdeficient mice is problematic because of compensation by surviving splice variants (Eliasson et al., 1997). We evaluated three inhibitors chosen to have good selectivity over eNOS in enzyme studies, namely 1400W (also a potent inhibitor of the inducible NO synthase, or iNOS), NPA, and L-VNIO (Alderton et al., 2001; Erdal et al., 2005). To assess their utility, rat hippocampal slices were stimulated with NMDA and the resulting accumulation of cGMP, which depends on nNOS, used to assay NO formation. To improve the signal-to-noise ratio, the slices were preincubated with EHNA, which is an inhibitor of a principal enzyme that hydrolyzes NO-evoked cGMP signals in the hippocampus, phosphodiesterase-2 (van Staveren et al., 2001; Suvarna and O'Donnell, 2002). Agreeing with past evidence (East and Garthwaite, 1991), NMDA (2 min exposure) generated a concentration-dependent accumulation of cGMP, peaking at 100 $\mu \mathrm{M}$ (Fig. 1A). The maximum amplitude was in the $10-20$ $\mathrm{pmol} / \mathrm{mg}$ protein range in different experiments and was lower than with a maximal exogenous $\mathrm{NO}$ exposure using the NONOate DEA/NO (Fig. 1A). L-VNIO and $1400 \mathrm{~W}$ were both potent inhibitors of the NMDA response, displaying $\mathrm{IC}_{50}$ values of $\sim 10$ 
A

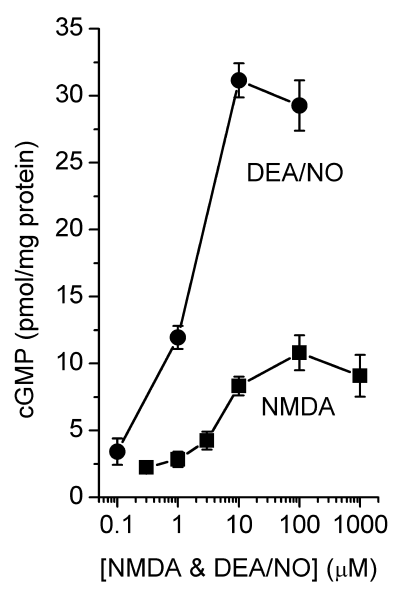

C Hippocampal slices

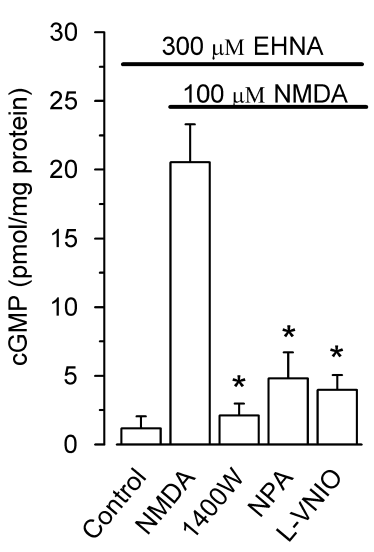

B

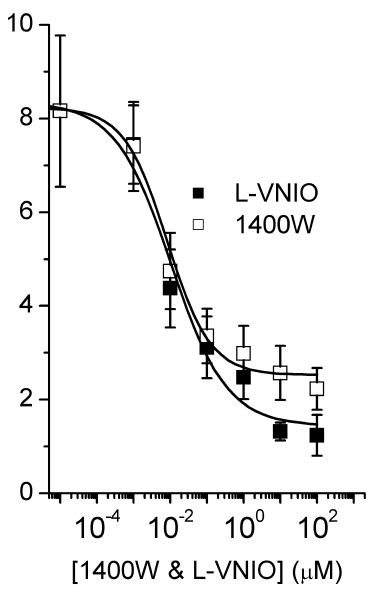

D Aortic rings

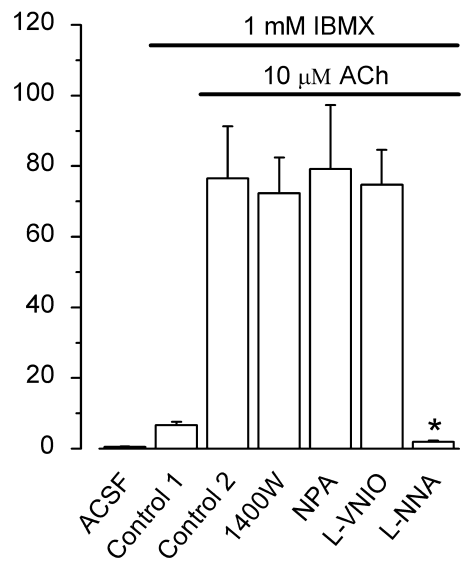

Figure 1. Identification of selective nNOS inhibitors. $A$, Concentration-response curves for NMDA and DEA/NO (both 2 min exposure) on cGMP levels in rat hippocampal slices incubated with the phosphodiesterase inhibitor EHNA $(300 \mu \mathrm{M})$. B , Concentration-dependent inhibition of the CGMP response to $100 \mu \mathrm{M}$ NMDA (in the presence of EHNA) by $1400 \mathrm{~W}$ and L-VNIO. C, Summary of the effects of 1400W $(1 \mu \mathrm{M}), \mathrm{NPA}(1 \mu \mathrm{M})$, and L-VNI0 $(0.1 \mu \mathrm{M})$ on NMDAstimulated CGMP levels. D, Lack of effect of these nNOS/iNOS inhibitors on acetylcholine (ACh)induced CGMP elevation in rings of rat aorta, a response inhibited by the nonselective NO synthase inhibitor L-NNA $(100 \mu \mathrm{m})$. The exposure to acetylcholine was for $1 \mathrm{~min}$, and the experiments in $\boldsymbol{C}$ and $\boldsymbol{D}$ were performed in parallel using the same reagents. ${ }^{*} p<0.001$ compared with NMDA or acetylcholine alone (control 2); $n=5$ (all panels). Data were analyzed by one-way ANOVA and Tukey's post hoc test.

nм (Fig. $1 B$ ). To test for selectivity, a direct comparison was made between cGMP generation in hippocampal slices in response to NMDA and in rings of rat aorta simulated with acetylcholine, a standard way of generating NO from eNOS in blood vessels (Furchgott and Zawadzki, 1980). 1400W (1 $\mu \mathrm{M})$ and L-VNIO (0.1 $\mu \mathrm{M})$, as well as a third compound, NPA $(1 \mu \mathrm{M})$, all inhibited the NMDA-stimulated response by $80-90 \%$ but failed to affect acetylcholine-stimulated eNOS activity significantly, although this activity could be abolished by L-NNA (Fig. 1C,D), which inhibits all NO synthases (Alderton et al., 2001; Erdal et al., 2005) and, accordingly, also blocks NMDA-evoked cGMP accumulation in hippocampal slices (East and Garthwaite, 1991).

\section{Source of tonic NO in hippocampal slices: tests for nNOS}

The level of cGMP sensitive to NO synthase inhibition is by far the most sensitive index of the prevailing endogenous NO concentration currently available (Griffiths et al., 2002). Even so,

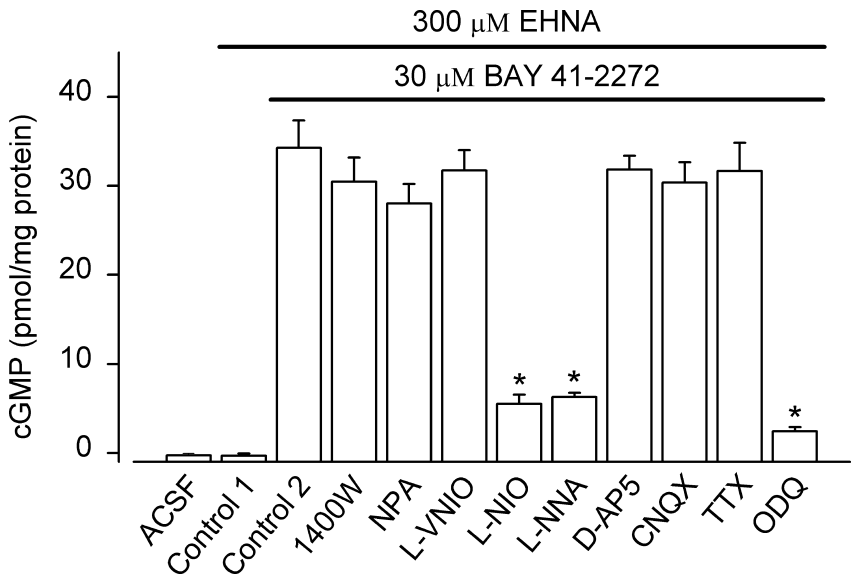

Figure 2. Origin of tonic $N 0$ in rat hippocampal slices. The nNOS/iNOS inhibitors $1400 \mathrm{~W}$ (1 $\mu \mathrm{M}), \mathrm{NPA}(1 \mu \mathrm{m})$, and L-VNIO $(0.1 \mu \mathrm{m})$ failed to reduce cGMP levels in the presence of BAY 41-2272 ( $p=0.66-1)$, whereas the nonselective NO synthase inhibitors L-NIO (100 $\mu \mathrm{m})$ and L-NNA $(100 \mu \mathrm{m})$ were both effective ( $\left.{ }^{*} p<0.001\right)$. The NMDA antagonist D-AP5 $(100 \mu \mathrm{m})$, AMPA antagonist CNQX (100 $\mu \mathrm{M})$, and $\mathrm{Na}^{+}$channel blocker tetrodotoxin (TTX, $\left.1 \mu \mathrm{M}\right)$ did not change cGMP levels in the presence of BAY 41-2272 significantly $(p=1)$, whereas ODQ, which blocks N0-stimulated GC activity, was strongly inhibitory. ${ }^{*} p<0.001 ; n=8-14$. Data were analyzed by one-way ANOVA and Tukey's post hoc test.

basal cGMP levels in hippocampal slices are on the verge of being undetectable, despite the presence of EHNA (Fig. 2 A). However, it was precisely this resting level that we wanted to investigate. Fortunately, new pharmacological tools that provide a solution to this problem have been discovered. One of these compounds is BAY 41-2272, an allosteric agonist for GC-coupled NO receptors exhibiting striking synergy with NO (Stasch et al., 2001). Compounds of this type slow the rate at which NO unbinds from the receptors up to several hundred-fold, thereby enhancing GC activity in the presence of low $\mathrm{NO}$ concentrations (Russwurm et al., 2002; Schmidt et al., 2003).

cGMP levels in hippocampal slices were greatly increased by $30 \mu \mathrm{M}$ BAY 41-2272 (Fig. 2). The response was reduced by the nonselective NO synthase inhibitors L-NNA and L-NIO, confirming that the activity of endogenous NO was primarily being potentiated. However, the response was not significantly changed by any of the three selective nNOS inhibitors, or by the NMDA antagonist D-AP5 (Fig. 2). AMPA receptors and voltagedependent $\mathrm{Na}^{+}$channels can also participate in NO synthase activation in brain slices (Southam et al., 1991), but inhibition of either (using CNQX and tetrodotoxin, respectively) failed to reduce hippocampal slice cGMP. In contrast, ODQ, the standard blocker of GC-coupled NO receptors (Garthwaite et al., 1995) produced a similar degree of inhibition to that seen with the nonselective NO synthase inhibitors. These results show that there is a tonic low level of NO in hippocampal slices and that the NO synthase isoform at work is unlikely to be nNOS. Moreover, the compound $1400 \mathrm{~W}$ is a potent inhibitor of iNOS, more so than of nNOS (Alderton et al., 2001; Erdal et al., 2005), but did not affect basal NO-dependent cGMP levels, suggesting that iNOS does not contribute either.

\section{Source of tonic NO in hippocampal slices: tests for eNOS}

Tonic eNOS activity in endothelial cells is typically maintained by phosphorylation, in part through the PI3 kinase-Akt pathway (Fulton et al., 2001). Two different PI3 kinase inhibitors, wortmannin $(1 \mu \mathrm{M})$ and LY294002 $(20 \mu \mathrm{M})$, both significantly reduced cGMP levels in rat hippocampal slices in the presence of 
A iNOS $\mathrm{nNOS}$ eNOS

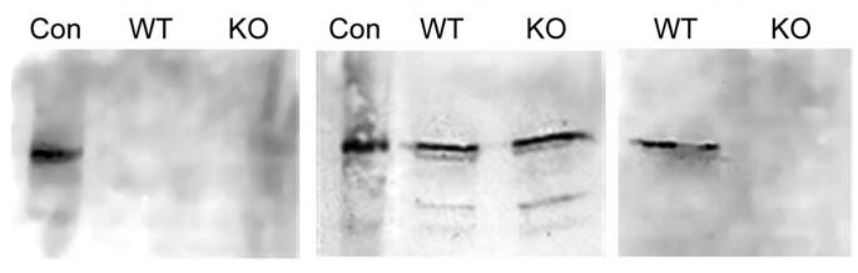

B

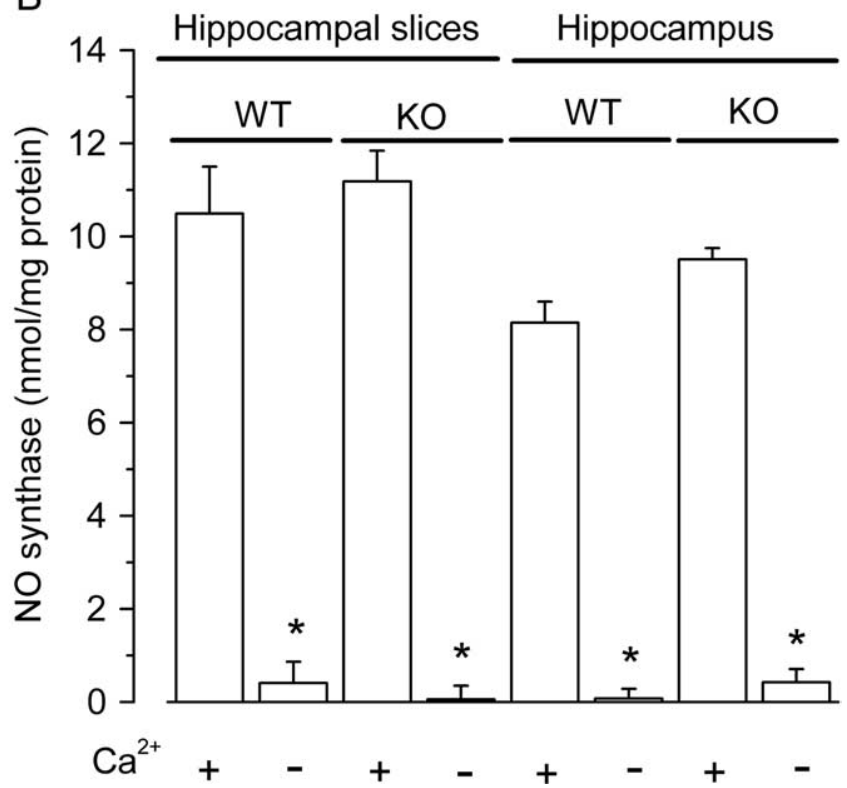

Figure 3. N0 synthase expression and activity in mouse hippocampus. $A$, Blot of extracts of wild-type (WT) and eNOS knock-out (KO) hippocampus labeled with antibodies against the different NO synthase isoforms, as indicated; Con indicates the protein standards specified in Materials and Methods. $\boldsymbol{B}, \mathrm{NO}$ synthase activity measured in the absence or presence of $\mathrm{Ca}^{2+}$ in extracts of whole hippocampus and of incubated hippocampal slices $\left(n=5\right.$; ${ }^{*} p<0.001$ compared with the presence of $\left.\mathrm{Ca}^{2+}\right)$. The activities in the presence of $\mathrm{Ca}^{2+}$ were not significantly different from each other, and the activities in the absence of $\mathrm{Ca}^{2+}$ were not significantly different from zero $(p=0.2-1)$.

BAY 41-2272 from $34 \pm 3 \mathrm{pmol} / \mathrm{mg}$ protein to $25 \pm 2$ and $17 \pm$ $3 \mathrm{pmol} / \mathrm{mg}$ protein, respectively $(n=14-15 ; p<0.05$ and $p<$ 0.001 , respectively), consistent with a participation of eNOS. To explore the role of eNOS more directly, and because no selective eNOS inhibitors exist yet, we resorted to the use of eNOS knockout mice. Checking NO synthase expression by Western blotting confirmed the absence of eNOS in the mutants, the presence of nNOS in mutants and wild-types, and a lack of detectable iNOS in either (Fig. 3A). To investigate iNOS further, NO synthase activity was directly assayed in fresh hippocampi and, in case iNOS may be inadvertently expressed in vitro, in hippocampal slices subjected to the usual incubation period. iNOS can be distinguished from the other isoforms by being $\mathrm{Ca}^{2+}$-independent but the activity in all cases was entirely $\mathrm{Ca}^{2+}$-dependent (Fig. $3 B$ ), further eliminating iNOS from consideration.

In wild-type mouse hippocampal slices, the three nNOS inhibitors (1400W, L-VNIO, and NPA) at the concentrations found to be selective in the rat tissue (Fig. $1 C$ ), retained their ability to block NMDA-stimulated cGMP formation to a similar extent to that seen in the rat (data not shown). Also duplicating results using the rat, exposure of mouse hippocampal slices to BAY 412272 caused cGMP levels to rise in a manner that was sensitive to

\section{A Wild-type}

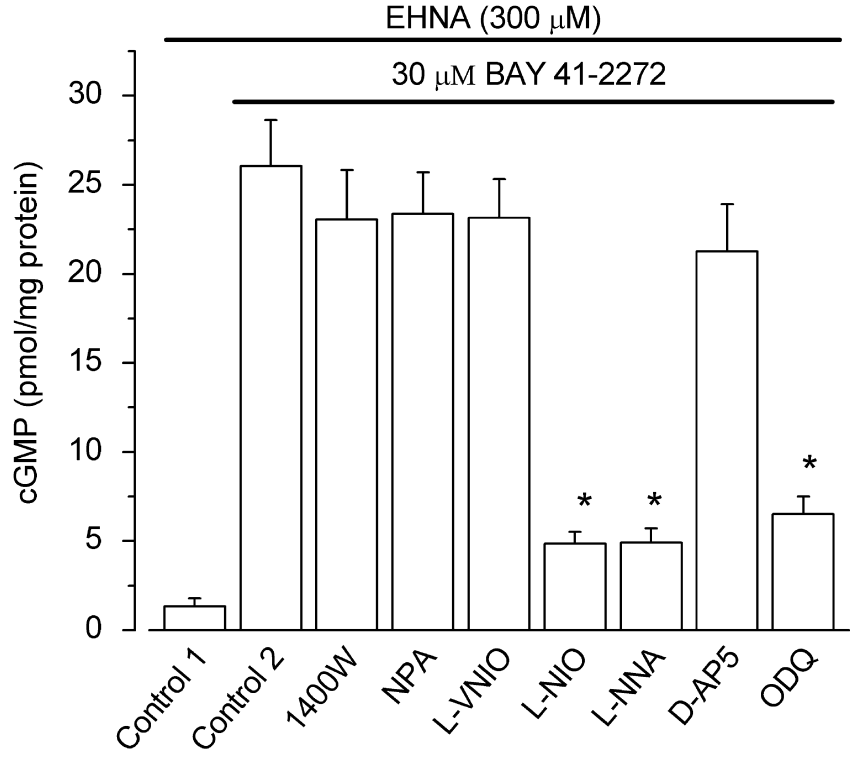

B eNOS knockout

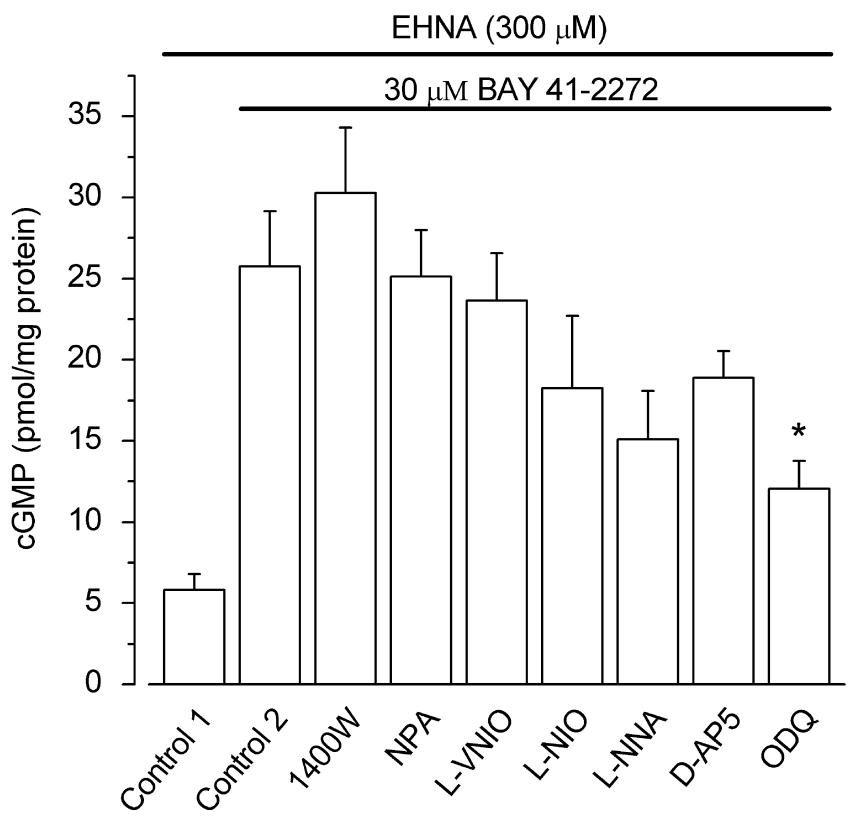

Figure 4. Tonic NO in wild-type and eNOS knock-out hippocampal slices. A, BAY 41-2272stimulated CGMP accumulation in wild-type slices was unaffected ( $p=0.97-0.98)$ by the nNOS/iNOS inhibitors 1400W $(1 \mu \mathrm{M})$, NPA $(1 \mu \mathrm{M})$, and L-VNI0 $(0.1 \mu \mathrm{M})$ or by $100 \mu \mathrm{M} \mathrm{D}-A P 5$ $(p=0.38)$ but was significantly reduced by L-NIO and L-NNA (both $100 \mu \mathrm{M}$ ), which are nonselective NO synthase inhibitors, or by ODQ $(10 \mu \mathrm{M})$, an inhibitor of NO-activated guanylyl cyclase $\left({ }^{*} p<0.001\right) . \boldsymbol{B}$, At the same concentrations used in $\boldsymbol{A}$, none of the N0 synthase inhibitors significantly reduced BAY 41-2272-stimulated CGMP accumulation in slices from eNOS knockout mice $(p=0.2-1)$. D-AP5 was also ineffective $(p=0.8)$, but the inhibition by $0 D Q$ was just significant. ${ }^{*} p=0.04 ; n=15$ in all cases. Data were analyzed by one-way ANOVA and Tukey's post hoc test.

nonselective NO synthase inhibition (L-NNA and L-NIO), and to blockade of GC-coupled NO receptors (ODQ), but was unaffected by the nNOS inhibitors and the NMDA antagonist D-AP5 (Fig. 4A). In hippocampal slices from eNOS knock-out animals, cGMP levels without BAY 41-2272 were already elevated but the inclusion of this compound enhanced them further (Fig. 4B). Despite this response to BAY 41-2272, none of the NO synthase 


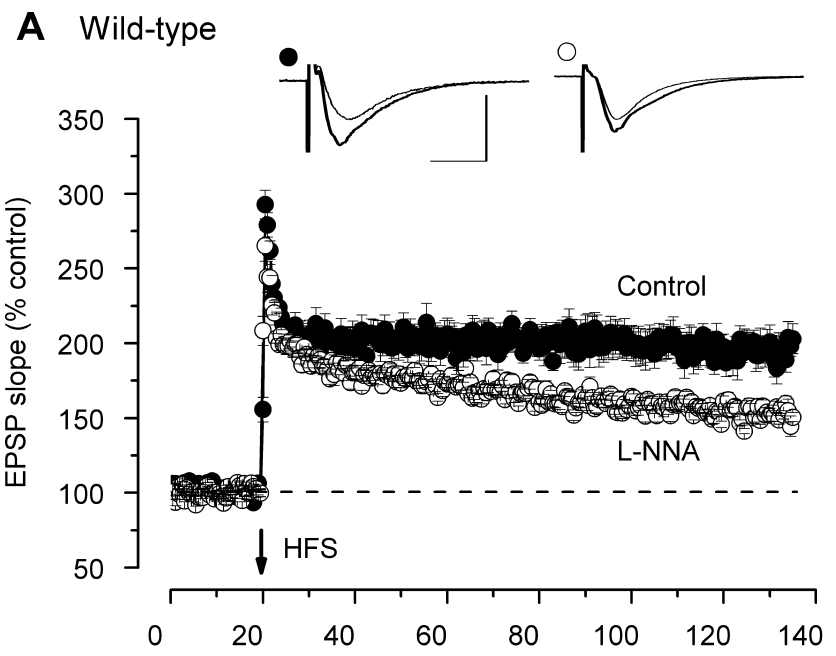

B eNOS knockout

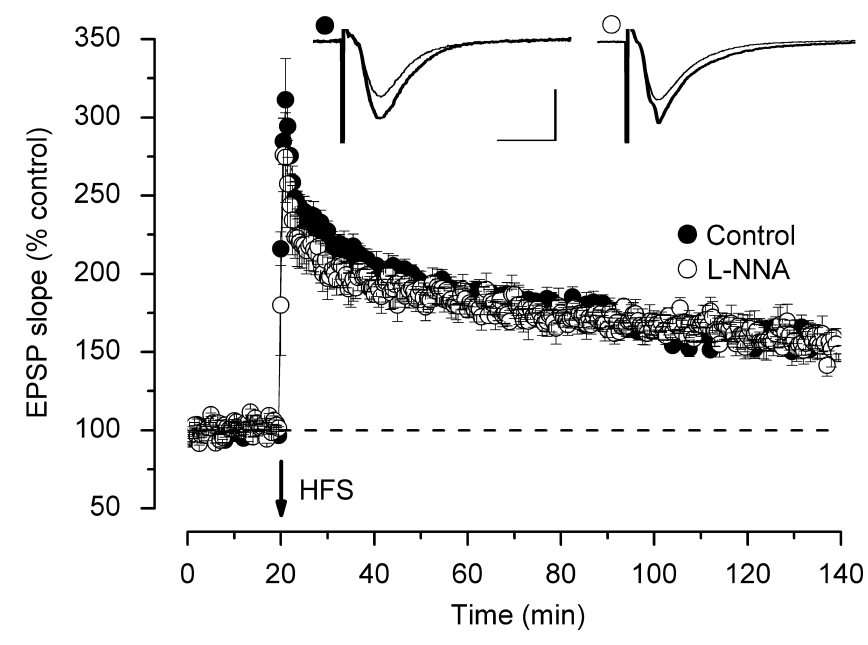

Figure 5. NO synthase and LTP in wild-type and eNOS knock-out mouse hippocampal slices. Tetanic stimulation (HFS; $100 \mathrm{~Hz}$ for $1 \mathrm{~s}$ ) was applied at the arrow. $A$, In wild types, the nonselective N0 synthase inhibitor L-NNA $(100 \mu \mathrm{M})$ caused a dwindling potentiation, contrasting with the sustained LTP seen in controls $(p<0.001)$. $\boldsymbol{B}$, In eNOS knock-out tissue, the control LTP was not sustained and L-NNA had no significant effect ( $p=0.77$ ). All data are $n=4-6$. Insets are representative traces taken just before tetanic stimulation (thin traces) and at the end of the recording (thick traces), the symbols identifying the experimental condition. Calibration: $1 \mathrm{mV}, 10 \mathrm{~ms}$.

inhibitors (selective or otherwise) significantly reduced cGMP levels (D-AP5 likewise) implying a lack of tonic endogenous NO formation, although ODQ retained some inhibitory effect.

\section{Role of eNOS in LTP}

The type of stimulation used to evoke LTP can have a bearing on its apparent NO-dependence, with lower intensity stimulus strengths favoring the participation of NO (Haley et al., 1993; O’Dell et al., 1994; Wilson et al., 1999). Two different stimulation protocols were therefore tested. The standard $100 \mathrm{~Hz}$ for $1 \mathrm{~s}$ stimulus elicited robust LTP in wild-type mice and the nonselective NO synthase inhibitor L-NNA caused a gradual loss of this LTP (Fig. 5A), a result very similar to that reported previously in rat and mouse hippocampal slices treated with NO synthase inhibitors (Bon and Garthwaite, 2003; Boulton et al., 1995; Ko and Kelly, 1999; Lu et al., 1999). In eNOS knock-out mouse hippocampal slices, only a decaying potentiation was seen (Fig. $5 B$ ), the time course of which was indistinguishable from that seen in
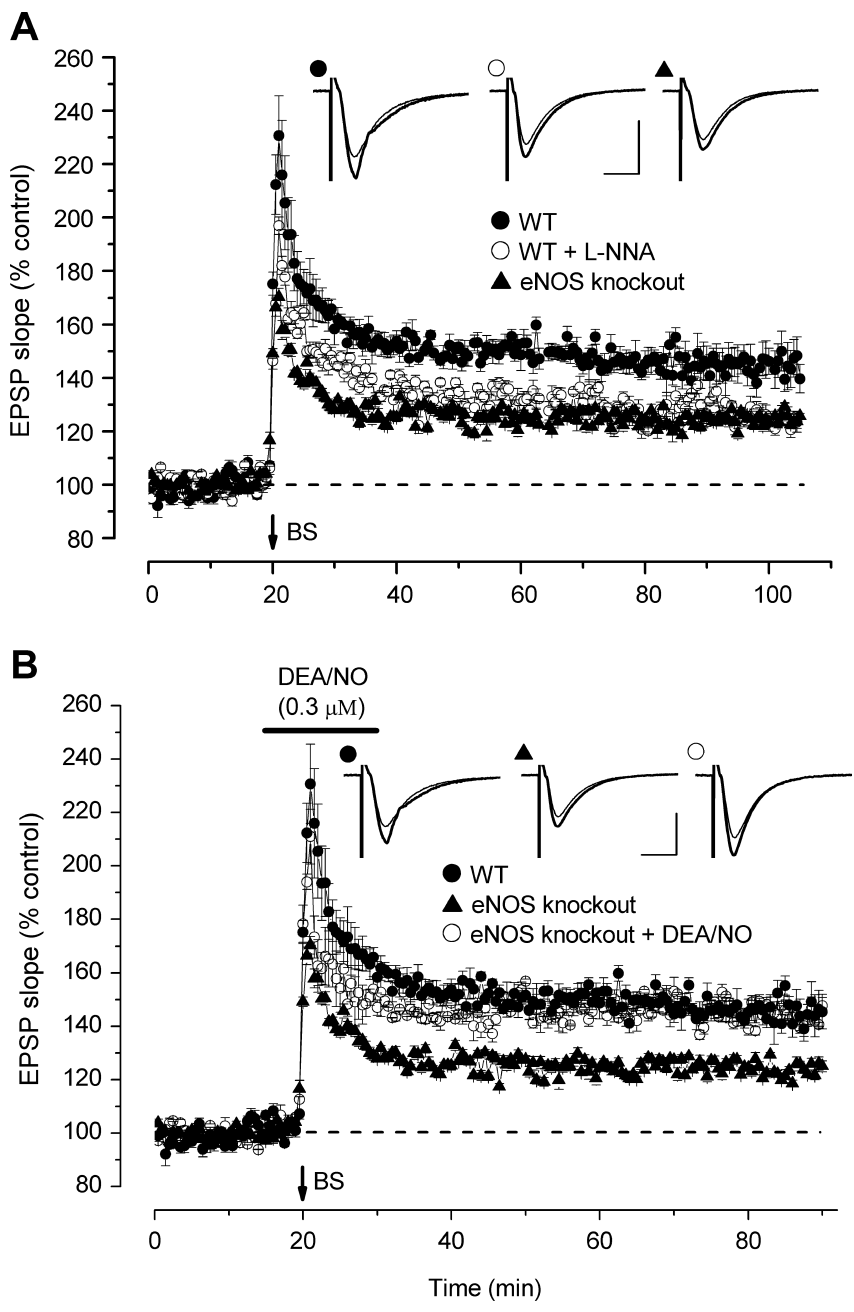

Figure 6. NO and LTP in wild-type and eNOS knock-out mouse hippocampus. A weak burst stimulation (BS; $3 \times 100 \mathrm{~Hz}$ for $100 \mathrm{~ms}$ ) was delivered at the arrow. $A$, Both eNOS knock-out tissue and wild types (WT) treated with the nonselective NO synthase inhibitor L-NNA (100 $\mu \mathrm{M})$ showed a diminished level of LTP not differing significantly from each other $(p=0.2)$ but significantly lower than that seen in wild-type controls $(p<0.001)$. B , The deficiency in LTP in the eNOS knock-outs was rescued by a low concentration of DEA/NO such that the level of potentiation was ultimately not significantly different from that observed in wild-type controls $(p=0.2)$. All data are $n=4-6$. Insets are representative traces taken just before tetanic stimulation (thin traces) and at the end of the recording (thick traces), the symbols identifying the experimental condition. Calibration: $1 \mathrm{mV}, 10 \mathrm{~ms}$.

wild-type tissue in the presence of L-NNA. Furthermore, L-NNA had no effect in the eNOS knock-out slices (Fig. 5B). Hence, the residual LTP is NO-independent.

The second protocol was designed to reproduce the burst-type stimulation reported by Wilson et al. (1999) to identify a loss of LTP in eNOS knock-out mice. In this, three successive stimuli, each at $100 \mathrm{~Hz}$ and of $100 \mathrm{~ms}$ duration, were delivered $20 \mathrm{~s}$ apart. This weak stimulation protocol produced sustained LTP, although the amplitude was reduced compared with that generated by $1 \mathrm{~Hz}$ for $1 \mathrm{~s}$ (Fig. 6A). Differing to some extent from the effect seen with stronger stimulation, L-NNA reduced all phases of the LTP, the residue appearing to remain stable for $>1 \mathrm{~h}$ (Fig. 6A). Application of the same weak stimulation to slices from eNOS knock-out mice produced a similarly diminished level of LTP, although the early phases (up to 30 min post-tetanus) were somewhat increased compared with the L-NNA-treated wild-type slices. 
A
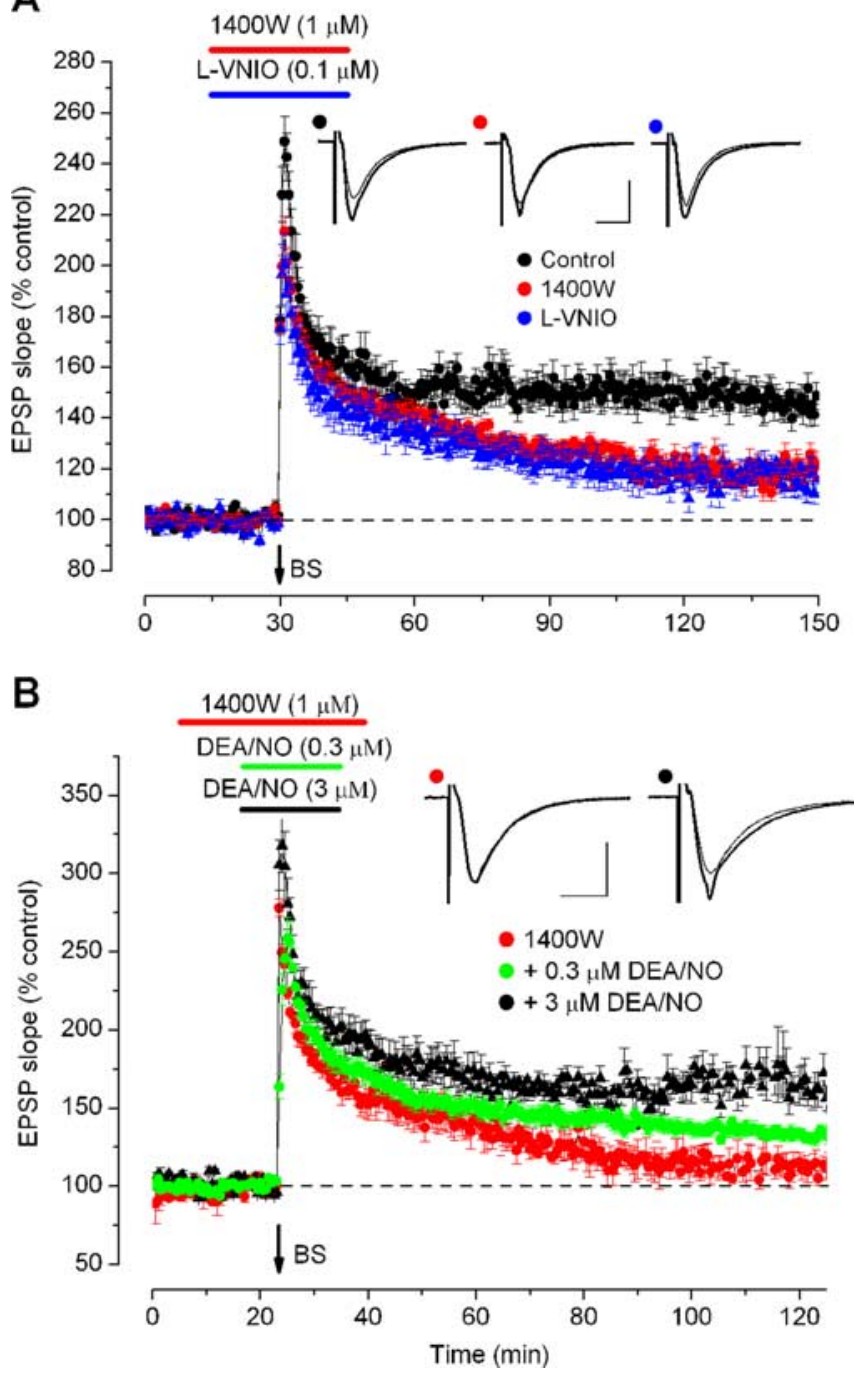

Figure 7. Role of nNOS in LTP in wild-type mouse hippocampus. Burst stimulation (BS) was delivered at the arrow. $A$, Two nNOS inhibitors inhibited LTP $(p<0.001)$, and their effects did not differ significantly ( $p=0.8)$. $B$, A low DEA/N0 concentration $(0.3 \mu \mathrm{m})$ significantly $(p<$ 0.001 ) but only partially rescued LTP from inhibition by $1400 \mathrm{~W}$, whereas a higher concentration $(3 \mu \mathrm{m})$ provided additional significant rescue $(p<0.001)$ and a sustained LTP resembling that seen in controls $(n=3-4)$. Insets are representative traces taken just before tetanic stimulation (thin traces) and at the end of the recording (thick traces), the symbols identifying the experimental conditions. Calibration: $1 \mathrm{mV}, 10 \mathrm{~ms}$.

Although the similarity in the LTP defects observed in eNOS knock-outs and in wild-types treated with the NO synthase inhibitor suggest that deficiencies of $\mathrm{NO}$ are responsible in both cases, distinguishing cause-and-effect with knock-out animals is often difficult because of secondary genetic and phenotypic alterations. Addressing this problem, we found that the deficit in eNOS knock-outs could be corrected by adding NO exogenously during a $15 \mathrm{~min}$ period spanning the burst stimulation (Fig. $6 \mathrm{~B}$ ). The exogenous NO was delivered using DEA/NO at a concentration $(0.3 \mu \mathrm{M})$ near the base of its concentration-response curve for cGMP generation in hippocampal slices (Fig. 1A). An identical DEA/NO application to wild-type slices did not affect LTP ( 147 vs $141 \%$ in controls during the period $60-80$ min posttetanus; $p<0.25$ ), showing that its effect in the eNOS knock-outs is restorative and not simply because of the addition of a potentiation produced by NO itself.

\section{Role of nNOS in LTP}

The foregoing results show that a lack of NO from eNOS leads to a deficit in LTP. The identification of agents selectively inhibiting nNOS (see above) provided the means for testing the role of this isoform as well. Using the burst stimulation protocol, both nNOS inhibitors tested (1400W and L-VNIO) caused identical effects: a gradually decaying level of potentiation returning almost to baseline within $2 \mathrm{~h}$ (Fig. 7A). Rescue was only partially achieved with the DEA/NO concentration $(0.3 \mu \mathrm{M})$ that successfully reinstated LTP in eNOS knock-out slices, but increasing the concentration to $3 \mu \mathrm{M}$, which is in the top half of the concentration-cGMP response curve (Fig. 1A) led to normal LTP being restored (Fig. $7 B)$. Control experiments showed that $3 \mu \mathrm{M}$ DEA/NO had no significant effect on the level of LTP in wild-type mouse hippocampal slices (153 $\pm 14 \% 70-90$ min post-tetanus; $p<0.25$ ), as has been reported previously (Puzzo et al., 2005).

\section{Discussion}

The results address two outstanding and closely related issues: the source of the tonic level of NO needed for LTP and the relative contribution of the two constitutive NO synthase isoforms, nNOS and eNOS, to LTP.

The discovery of compounds such as BAY 41-2272 that boost GC activity in response to very low NO concentrations allowed the source of the tonic NO to be investigated with unsurpassed sensitivity and finding inhibitor concentrations specific for nNOS over eNOS also permitted nNOS to be examined. Inhibition of nNOS or NMDA receptors failed to affect the tonic NO levels. Together with an absence of demonstrable iNOS and the lack of effect of a potent iNOS inhibitor (1400W), the process of elimination points to eNOS being the isoform at work. Positive evidence was obtained in slices from eNOS knock-out mice, where tonic NO synthase activity was undetectable.

Despite their deficit in tonic NO, the eNOS knock-out hippocampal slices showed elevated basal cGMP levels in the presence of EHNA and a normal cGMP elevation on the additional exposure to BAY 41-2272 that was partially sensitive to ODQ. These results bear some similarities with findings in the cardiovascular system of eNOS knock-out mice where cGMP formation from other sources is enhanced (Hussain et al., 2001; Gyurko et al., 2000) and where the compound YC-1, which (like BAY 412272) acts synergistically with NO, retains its relaxing effect (Hussain et al., 1999). The sustained activity of the compounds in the knock-outs may reflect an amplification of the normally small component of their action that is NO-independent (Stasch et al., 2001), a component visible in Figures 2 and $4 A$. Another explanation might be that there is an increase in endogenous carbon monoxide to levels capable of stimulating cGMP formation when BAY 41-2272 is present (Friebe et al., 1996). Regardless of the true reason, the switch from a largely NO-driven to a largely NO-independent cGMP level in the eNOS knock-outs observed under the magnifying influence of EHNA and BAY 41-2272 did not translate into a compensatory mechanism for maintaining LTP when recorded in the absence of these pharmacological agents.

According with its role in generating the tonic NO, eNOS can synthesize NO continuously under physiological conditions (Fulton et al., 2001). This is explained by the enzyme, although $\mathrm{Ca}^{2+}$-dependent, possessing phosphorylation sites that permit 15- to 20-fold stimulation of NO synthase activity at resting levels of cytosolic $\mathrm{Ca}^{2+}$. One phosphorylation mechanism of importance in blood vessels is through the kinase Akt, which is activated downstream of the PI3 kinase signaling pathway (Fulton et al., 
2001) and, based on the effect of the P13 kinase inhibitors, this pathway appeared to be partially responsible for sustaining eNOS activity in rat hippocampal slices.

The location of eNOS in the hippocampus has been controversial. It was originally reported to be in CA1 pyramidal cells (Dinerman et al., 1994). However, subsequent studies by the same laboratory (Demas et al., 1999; Blackshaw et al., 2003) and others (Seidel et al., 1997; Stanarius et al., 1997; Topel et al., 1998) could not confirm this result and, instead, concluded that eNOS mRNA and protein were found only in endothelial cells. Hence, the tonic NO we measured is likely to come from this source. In one sense, this is not surprising. In larger blood vessels, endothelium-derived NO diffuses to the underlying smooth muscle cell layers up to several $100 \mu \mathrm{m}$ thick to elicit relaxation whereas, throughout the brain, eNOS is found in capillaries (Seidel et al., 1997; Stanarius et al., 1997) that are maximally only $\sim 25$ $\mu \mathrm{m}$ away from any neuronal or glial element (Pawlik et al., 1981). Furthermore, tonic NO generation from the three-dimensional array of capillaries is theoretically an effective way for supplying the parenchyma with a global NO concentration (Tsoukias and Popel, 2003). Based on the steady-state sensitivity of GC-coupled NO receptors in cells to NO ( $\mathrm{EC}_{50} \sim 2 \mathrm{nM}$ ) (Griffiths et al., 2002) and the resting level of cGMP in hippocampal slices (1-3 $\mathrm{pmol} / \mathrm{mg}$ protein) relative to the maximum achievable with exogenous $\mathrm{NO}(\sim 30 \mathrm{pmol} / \mathrm{mg}$ protein $)$, the effective concentration in the parenchyma is likely to be subnanomolar. Although very low, NO concentrations in this range can activate cGMPdependent protein kinase in cells $\left(\mathrm{EC}_{50}=0.5 \mathrm{nM}\right.$ ) (Mo et al., 2004), so are biologically important.

Previous findings on the roles of nNOS and eNOS in LTP have also been perplexing. It was first reported that LTP was preserved in nNOS deficient mice (O'Dell et al., 1994) a result explained by eNOS being located in pyramidal cells (now considered incorrect; see above). Subsequently, LTP was shown to be largely preserved in eNOS knock-out mice, but lost when eNOS and nNOS were both deleted (Son et al., 1996), whereas others using either a presumed dominant-negative eNOS construct (Kantor et al., 1996) or eNOS knock-out mice (Wilson et al., 1999) reported a major loss of LTP. Our results emphasize a role of eNOS in LTP although, for reasons that are uncertain, only a partial loss of LTP in eNOS knock-out tissue occurred under conditions where Wilson et al. (1999) observed a more complete block. More importantly, we report that the deficit in LTP can be rescued by administration of exogenous NO, providing the best evidence to date that the deficiency in the eNOS knock-out is at the level of NO generation. The concentration and duration of the restorative NO application were the same as those needed to mimic the tonic, low-level NO exposure needed to facilitate LTP when NO synthases are blocked in rat hippocampal slices (Bon and Garthwaite, 2003).

On reinvestigating the role of nNOS using two different inhibitors of demonstrated selectivity, a profound dissipation of the later phases of LTP was observed and this too could be rescued by exogenous NO. In this case, however, complete restoration required a higher concentration than was needed to substitute for the lack of eNOS. This result is consistent with the increased NMDA receptor-dependent NO release found on tetanic stimulation (Chetkovich et al., 1993; Monfort et al., 2002) being important for LTP. It is also consistent with a requirement for the same higher NO concentration to be paired with weak presynaptic stimulation to generate LTP (Bon and Garthwaite, 2003). The maintained LTP in nNOS-deficient mice (Son et al.,
1996) may be attributable to compensation by residual nNOS splice variants (Eliasson et al., 1997).

The overall conclusions now to be drawn are that eNOS in endothelial cells generates the tonic level of NO whereas nNOS present in hippocampal pyramidal cells (Burette et al., 2002; Blackshaw et al., 2003) produces the phasic NO signal in association with NMDA receptor stimulation (Chetkovich et al., 1993; Monfort et al., 2002), and that both are important for CA1 hippocampal LTP. This new scenario immediately raises questions as to where and how these different signals are acting. By analogy with a prominent mechanism in blood vessels (Sauzeau et al., 2000; Somlyo and Somlyo, 2003), one might speculate that tonic NO from eNOS acts pervasively through cGMP and cGMPdependent protein kinase to counteract the stabilizing effect of the Rho kinase pathway on the dendritic and axonal cytoskeletons (Nakayama et al., 2000; Bito et al., 2000), thereby priming presynaptic and/or postsynaptic elements for structural change (Matus, 2000). Phasic NO from nNOS, however, may serve a much more synapse-specific role than previously thought, allowing temporal information about postsynaptic NMDA receptor activity to be faithfully coded into cGMP levels in the immediately adjacent presynaptic terminal and/or in the dendritic spine (Garthwaite, 2005). Consonant with this role is the report that nNOS and NO-activated GC are located in juxtaposed postsynaptic and presynaptic elements in the CA1 hippocampus (Burette et al., 2002). This discrete NO signal may serve both as a retrograde messenger and a signal for postsynaptic gene expression (Lu et al., 1999). The positioning of the brain-enriched $\alpha 2 \beta 1$ isoform of GC-coupled NO receptors within presynaptic or postsynaptic protein scaffold complexes (Russwurm et al., 2001) would be convenient for transducing such localized NO signals.

Finally, expanding on our recent finding that blood vessels signal to central axons through NO (Garthwaite et al., 2006), the notion emerges that blood vessels can influence synaptic plasticity in the brain, also through release of NO. Circumstantial evidence consistent with this hypothesis derives from behavioral tests in several species, indicating that tonic NO and cGMP contribute to memory formation (for review, see Bon and Garthwaite, 2003). Furthermore, as in the hippocampus, defective synaptic plasticity has been recorded in eNOS knock-outs in the cerebral cortex and striatum (Haul et al., 1999; Doreulee et al., 2003), where eNOS is also localized to blood vessels (Stanarius et al., 1997; Topel et al., 1998). In the solitary tract nucleus, eNOS regulates autonomic function (Paton et al., 2002) and mice lacking eNOS exhibit various behavioral and neurochemical abnormalities (Kano et al., 1998; Demas et al., 1999; Frisch et al., 2000), and decreased neurogenesis (Reif et al., 2004; Chen et al., 2005). The line of communication between endothelial cells and neurons in the brain might be widespread.

\section{References}

Alderton WK, Cooper CE, Knowles RG (2001) Nitric oxide synthases: structure, function and inhibition. Biochem J 357:593-615.

Arancio O, Kiebler M, Lee CJ, Lev Ram V, Tsien RY, Kandel ER, Hawkins RD (1996) Nitric oxide acts directly in the presynaptic neuron to produce long-term potentiation in cultured hippocampal neurons. Cell 87:1025-1035.

Bito H, Furuyashiki T, Ishihara H, Shibasaki Y, Ohashi K, Mizuno K, Maekawa M, Ishizaki T, Narumiya S (2000) A critical role for a Rhoassociated kinase, p160ROCK, in determining axon outgrowth in mammalian CNS neurons. Neuron 26:431-441.

Blackshaw S, Eliasson MJ, Sawa A, Watkins CC, Krug D, Gupta A, Arai T, Ferrante RJ, Snyder SH (2003) Species, strain and developmental variations in hippocampal neuronal and endothelial nitric oxide synthase clar- 
ify discrepancies in nitric oxide-dependent synaptic plasticity. Neuroscience 119:979-990.

Bliss TV, Collingridge GL (1993) A synaptic model of memory: long-term potentiation in the hippocampus. Nature 361:31-39.

Bon CL, Garthwaite J (2003) On the role of nitric oxide in hippocampal long-term potentiation. J Neurosci 23:1941-1948.

Boulton CL, Southam E, Garthwaite J (1995) Nitric oxide-dependent longterm potentiation is blocked by a specific inhibitor of soluble guanylyl cyclase. Neuroscience 69:699-703.

Brenman JE, Bredt DS (1997) Synaptic signaling by nitric oxide. Curr Opin Neurobiol 7:374-378.

Burette A, Zabel U, Weinberg RJ, Schmidt HH, Valtschanoff JG (2002) Synaptic localization of nitric oxide synthase and soluble guanylyl cyclase in the hippocampus. J Neurosci 22:8961-8970.

Chen J, Zacharek A, Zhang C, Jiang H, Li Y, Roberts C, Lu M, Kapke A, Chopp M (2005) Endothelial nitric oxide synthase regulates brain-derived neurotrophic factor expression and neurogenesis after stroke in mice. J Neurosci 25:2366-2375.

Chetkovich DM, Klann E, Sweatt JD (1993) Nitric oxide synthaseindependent long-term potentiation in area $\mathrm{CAl}$ of hippocampus. NeuroReport 4:919-922.

Demas GE, Kriegsfeld LJ, Blackshaw S, Huang P, Gammie SC, Nelson RJ, Snyder SH (1999) Elimination of aggressive behavior in male mice lacking endothelial nitric oxide synthase. J Neurosci 19: RC30.

Dinerman JL, Dawson TM, Schell MJ, Snowman A, Snyder SH (1994) Endothelial nitric oxide synthase localized to hippocampal pyramidal cells: implications for synaptic plasticity. Proc Natl Acad Sci USA 91:4214-4218.

Doreulee N, Sergeeva OA, Yanovsky Y, Chepkova AN, Selbach O, Godecke A, Schrader J, Haas HL (2003) Cortico-striatal synaptic plasticity in endothelial nitric oxide synthase deficient mice. Brain Res 964:159-163.

Doyle C, Holscher C, Rowan MJ, Anwyl R (1996) The selective neuronal NO synthase inhibitor 7-nitro-indazole blocks both long-term potentiation and depotentiation of field EPSPs in rat hippocampal CA1 in vivo. J Neurosci 16:418-424

East SJ, Garthwaite J (1991) NMDA receptor activation in rat hippocampus induces cyclic GMP formation through the L-arginine-nitric oxide pathway. Neurosci Lett 123:17-19.

Eliasson MJ, Blackshaw S, Schell MJ, Snyder SH (1997) Neuronal nitric oxide synthase alternatively spliced forms: prominent functional localizations in the brain. Proc Natl Acad Sci USA 94:3396-3401.

Erdal EP, Litzinger EA, Seo J, Zhu Y, Ji H, Silverman RB (2005) Selective neuronal nitric oxide synthase inhibitors. Curr Top Med Chem 5:603-624.

Feil R, Hofmann F, Kleppisch T (2005) Function of cGMP-dependent protein kinases in the nervous system. Rev Neurosci 16:23-41.

Friebe A, Schultz G, Koesling D (1996) Sensitizing soluble guanylyl cyclase to become a highly CO-sensitive enzyme. EMBO J 15:6863-6868.

Frisch C, Dere E, Silva MA, Godecke A, Schrader J, Huston JP (2000) Superior water maze performance and increase in fear-related behavior in the endothelial nitric oxide synthase-deficient mouse together with monoamine changes in cerebellum and ventral striatum. J Neurosci 20:6694-6700

Fulton D, Gratton JP, Sessa WC (2001) Post-translational control of endothelial nitric oxide synthase: why isn't calcium/calmodulin enough? J Pharmacol Exp Ther 299:818-824.

Furchgott RF, Zawadzki JV (1980) The obligatory role of endothelial cells in the relaxation of arterial smooth muscle by acetylcholine. Nature 288:373-376.

Garthwaite G, Bartus K, Malcolm D, Goodwin DA, Kollb-Sielecka M, Dooldeniya C, Garthwaite J (2006) Signaling from blood vessels to CNS axons through nitric oxide. J Neurosci 26:7730-7740.

Garthwaite J (2005) Dynamics of cellular NO-cGMP signaling. Front Biosci 10:1868-1880.

Garthwaite J, Boulton CL (1995) Nitric oxide signaling in the central nervous system. Annu Rev Physiol 57:683-706.

Garthwaite J, Southam E, Boulton CL, Nielsen EB, Schmidt K, Mayer B (1995) Potent and selective inhibition of nitric oxide-sensitive guanylyl cyclase by $1 \mathrm{H}-[1,2,4]$ oxadiazolo[4,3-a] quinoxalin-1-one. Mol Pharmacol 48:184-188.

Griffiths C, Garthwaite G, Goodwin DA, Garthwaite J (2002) Dynamics of nitric oxide during simulated ischaemia-reperfusion in rat striatal slices measured using an intrinsic biosensor, soluble guanylyl cyclase. Eur J Neurosci 15:962-968.

Gyurko R, Kuhlencordt P, Fishman MC, Huang PL (2000) Modulation of mouse cardiac function in vivo by eNOS and ANP. Am J Physiol Heart Circ Physiol 278:H971-H981.

Haley JE, Malen PL, Chapman PF (1993) Nitric oxide synthase inhibitors block long-term potentiation induced by weak but not strong tetanic stimulation at physiological brain temperatures in rat hippocampal slices. Neurosci Lett 160:85-88.

Haul S, Godecke A, Schrader J, Haas HL, Luhmann HJ (1999) Impairment of neocortical long-term potentiation in mice deficient of endothelial nitric oxide synthase. J Neurophysiol 81:494-497.

Huang PL, Huang Z, Mashimo H, Bloch KD, Moskowitz MA, Bevan JA, Fishman MC (1995) Hypertension in mice lacking the gene for endothelial nitric oxide synthase. Nature 377:239-242.

Hussain MB, Hobbs AJ, MacAllister RJ (1999) Autoregulation of nitric oxide-soluble guanylate cyclase-cyclic GMP signalling in mouse thoracic aorta. Br J Pharmacol 128:1082-1088.

Hussain MB, MacAllister RJ, Hobbs AJ (2001) Reciprocal regulation of cGMP-mediated vasorelaxation by soluble and particulate guanylate cyclases. Am J Physiol Heart Circ Physiol 280:H1151-H1159.

Kano T, Shimizu-Sasamata M, Huang PL, Moskowitz MA, Lo EH (1998) Effects of nitric oxide synthase gene knock-out on neurotransmitter release in vivo. Neuroscience 86:695-699.

Kantor DB, Lanzrein M, Stary SJ, Sandoval GM, Smith WB, Sullivan BM, Davidson N, Schuman EM (1996) A role for endothelial NO synthase in LTP revealed by adenovirus-mediated inhibition and rescue. Science 274:1744-1748.

Knowles RG, Salter M (1998) Measurement of NOS activity by conversion of radiolabeled arginine to citrulline using ion-exchange separation. Methods Mol Biol 100:67-73.

Ko GY, Kelly PT (1999) Nitric oxide acts as a postsynaptic signaling molecule in calcium/calmodulin-induced synaptic potentiation in hippocampal CA1 pyramidal neurons. J Neurosci 19:6784-6794.

Lu YF, Kandel ER, Hawkins RD (1999) Nitric oxide signaling contributes to late-phase LTP and CREB phosphorylation in the hippocampus. J Neurosci 19:10250-10261.

Malen PL, Chapman PF (1997) Nitric oxide facilitates long-term potentiation, but not long-term depression. J Neurosci 17:2645-2651.

Matus A (2000) Actin-based plasticity in dendritic spines. Science 290:754-758.

Micheva KD, Buchanan J, Holz RW, Smith SJ (2003) Retrograde regulation of synaptic vesicle endocytosis and recycling. Nat Neurosci 6:925-932.

Mo E, Amin H, Bianco IH, Garthwaite J (2004) Kinetics of a cellular nitric oxide/cGMP/phosphodiesterase-5 pathway. J Biol Chem 279:26149-26158.

Monfort P, Munoz MD, Kosenko E, Felipo V (2002) Long-term potentiation in hippocampus involves sequential activation of soluble guanylate cyclase, cGMP-dependent protein kinase, and cGMP-degrading phosphodiesterase. J Neurosci 22:10116-10122.

Nakayama AY, Harms MB, Luo L (2000) Small GTPases Rac and Rho in the maintenance of dendritic spines and branches in hippocampal pyramidal neurons. J Neurosci 20:5329-5338.

O’Dell TJ, Huang PL, Dawson TM, Dinerman JL, Snyder SH, Kandel ER, Fishman MC (1994) Endothelial NOS and the blockade of LTP by NOS inhibitors in mice lacking neuronal NOS. Science 265:542-546.

Paton JF, Kasparov S, Paterson DJ (2002) Nitric oxide and autonomic control of heart rate: a question of specificity. Trends Neurosci 25:626-631.

Pawlik G, Rackl A, Bing RJ (1981) Quantitative capillary topography and blood flow in the cerebral cortex of cats: an in vivo microscopic study. Brain Res 208:35-58.

Prast H, Philippu A (2001) Nitric oxide as modulator of neuronal function. Prog Neurobiol 64:51-68.

Puzzo D, Vitolo O, Trinchese F, Jacob JP, Palmeri A, Arancio O (2005) Amyloid-beta peptide inhibits activation of the nitric oxide/cGMP/ cAMP-responsive element-binding protein pathway during hippocampal synaptic plasticity. J Neurosci 25:6887-6897.

Reif A, Schmitt A, Fritzen S, Chourbaji S, Bartsch C, Urani A, Wycislo M, Mossner R, Sommer C, Gass P, Lesch KP (2004) Differential effect of endothelial nitric oxide synthase (NOS-III) on the regulation of adult neurogenesis and behaviour. Eur J Neurosci 20:885-895.

Russwurm M, Wittau N, Koesling D (2001) Guanylyl cyclase/PSD-95 inter- 
action: targeting of the NO-sensitive $\alpha_{2} \beta_{1}$ guanylyl cyclase to synaptic membranes. J Biol Chem 276:44647-44652.

Russwurm M, Mergia E, Mullershausen F, Koesling D (2002) Inhibition of deactivation of NO-sensitive guanylyl cyclase accounts for the sensitizing effect of YC-1. J Biol Chem 277:24883-24888.

Sauzeau V, Le Jeune H, Cario-Toumaniantz C, Smolenski A, Lohmann SM, Bertoglio J, Chardin P, Pacaud P, Loirand G (2000) Cyclic GMPdependent protein kinase signaling pathway inhibits RhoA-induced $\mathrm{Ca}^{2+}$ sensitization of contraction in vascular smooth muscle. J Biol Chem 275:21722-21729.

Schmidt P, Schramm M, Schroder H, Stasch JP (2003) Mechanisms of nitric oxide independent activation of soluble guanylyl cyclase. Eur J Pharmacol 468:167-174.

Seidel B, Stanarius A, WolfG (1997) Differential expression of neuronal and endothelial nitric oxide synthase in blood vessels of the rat brain. Neurosci Lett 239:109-112.

Somlyo AP, Somlyo AV (2003) $\mathrm{Ca}^{2+}$ sensitivity of smooth muscle and nonmuscle myosin II: modulated by $\mathrm{G}$ proteins, kinases, and myosin phosphatase. Physiol Rev 83:1325-1358.

Son H, Hawkins RD, Martin K, Kiebler M, Huang PL, Fishman MC, Kandel ER (1996) Long-term potentiation is reduced in mice that are doubly mutant in endothelial and neuronal nitric oxide synthase. Cell 87:1015-1023.

Southam E, East SJ, Garthwaite J (1991) Excitatory amino acid receptors coupled to the nitric oxide/cyclic GMP pathway in rat cerebellum during development. J Neurochem 56:2072-2081.

Stanarius A, Topel I, Schulz S, Noack H, Wolf G (1997) Immunocytochemistry of endothelial nitric oxide synthase in the rat brain: a light and electron microscopical study using the tyramide signal amplification technique. Acta Histochem 99:411-429.

Stasch JP, Becker EM, Alonso-Alija C, Apeler H, Dembowsky K, Feurer A, Gerzer R, Minuth T, Perzborn E, Pleiss U, Schroder H, Schroeder W, Stahl E, Steinke W, Straub A, Schramm M (2001) NO-independent regulatory site on soluble guanylate cyclase. Nature 410:212-215.

Susswein AJ, Katzoff A, Miller N, Hurwitz I (2004) Nitric oxide and memory. Neuroscientist 10:153-162.

Suvarna NU, O'Donnell JM (2002) Hydrolysis of $N$-methyl-D-aspartate receptor-stimulated cAMP and cGMP by PDE4 and PDE2 phosphodiesterases in primary neuronal cultures of rat cerebral cortex and hippocampus. J Pharmacol Exp Ther 302:249-256.

Topel I, Stanarius A, Wolf G (1998) Distribution of the endothelial constitutive nitric oxide synthase in the developing rat brain: an immunohistochemical study. Brain Res 788:43-48.

Tsoukias NM, Popel AS (2003) A model of nitric oxide capillary exchange. Microcirculation 10:479-495.

van Staveren WC, Markerink-Van Ittersum M, Steinbusch HW, de Vente J (2001) The effects of phosphodiesterase inhibition on cyclic GMP and cyclic AMP accumulation in the hippocampus of the rat. Brain Res 888:275-286.

Wilson RI, Godecke A, Brown RE, Schrader J, Haas HL (1999) Mice deficient in endothelial nitric oxide synthase exhibit a selective deficit in hippocampal long-term potentiation. Neuroscience 90:1157-1165.

Zhuo M, Small SA, Kandel ER, Hawkins RD (1993) Nitric oxide and carbon monoxide produce activity-dependent long-term synaptic enhancement in hippocampus. Science 260:1946-1950. 